\title{
Ecobordure: A flora-based indicator to assess vegetation patterns of field margins and infer its local drivers. Design in Brittany (France)
}

\author{
Audrey Alignier ${ }^{\mathrm{a}, \mathrm{b}, *, 1}$, Didier Le Cœur ${ }^{\mathrm{c}, 1}$, Elven Lanoë ${ }^{\mathrm{a}}$, Fabien Ferchaud ${ }^{\mathrm{d}}$, Bénédicte Roche ${ }^{\mathrm{a}}$, \\ Claudine Thenail ${ }^{\mathrm{a}}$ \\ a INRA, UMR 0980 BAGAP, CS 84215, 35042 Rennes Cedex, France \\ ${ }^{\mathrm{b}}$ LTER-“Zone Atelier Armorique”, UMR 0980 BAGAP, CS 84215, 35042 Rennes Cedex, France \\ ' Agrocampus Ouest, UMR 0980 BAGAP, CS 84215, 35042 Rennes Cedex, France \\ d INRA, UR 1158 AgroImpact, Site de Laon, F-02000 Barenton-Bugny, France
}

\section{A R T I C L E I N F O}

\section{Keywords:}

Indicator

Vegetation

Field margin

Management practice

Agricultural adviser

Agroecology

\begin{abstract}
A B S T R A C T
Field margins are key landscape elements contributing to maintain biodiversity in agricultural landscapes. Yet, their ecological value is often poorly assessed and restricted to landscape descriptors, e.g. density or structure of hedgerows. We introduce Ecobordure, a flora-based indicator designed to describe vegetation patterns of field margins and infer on drivers leading to these patterns, i.e. structure and management practices of field margins. Ecobordure first targets agricultural teachers and advisers, who want to learn and help students and farmers to learn about patterns and drivers of field margin vegetation, for promoting management practices favorable to this biodiversity. Here, we present the stages of the Ecobordure design and output validation. The first stage consisted of elucidating the relationship between vegetation composition and structural and management characteristics of field margins. Canonical Correspondence Analyses were performed on empirical datasets derived from field work in bocage regions of Brittany (north-western France). This first stage led to the selection of 31 reference species, quite common, easy-to-recognize and representative of i) the whole community and ii) a wide range of ecological attributes. The 31 reference species were classified in three groups sharing similar life history traits and ecological attributes: "forest-edge", "grassland" and "weed" species. The second stage consisted of the graphical representation of field margins in a triplot diagram, the "Ecobordure triangle", according to the relative percentage of the three species groups. The representation of the Ecobordure triangle was then refined through segmentation in seven sectors to facilitate the reading and interpretation of results. Finally, the output validation of the indicator was performed by testing the consistency between Ecobordure outputs and structural and management characteristics of field margins, using an independent dataset. Our results demonstrate that Ecobordure is a simple, efficient and reliable indicator allowing users to characterize vegetation patterns of field margins and identify potential drivers leading to these patterns. In its original form, Ecobordure can be applied to a broad spectrum of field margins in European bocage regions with temperate oceanic climate, on acidic to neutral soil. However, its use can be extended to other agricultural regions through adaptation of the species list. We conclude by giving some information about Ecobordure use and appropriation by end users.
\end{abstract}

\section{Introduction}

Biodiversity in agricultural landscapes is associated with both seminatural elements, e.g. woodland and hedgerows, and productive even intensively-managed elements such as crop and grassland fields (Fahrig et al., 2011). All these elements are interspersed in landscapes and inter-related by structural relationships, ecological processes and agricultural management decisions (Burel and Baudry, 1999). Therefore, segregating areas for conservation cannot be the only way to manage and maintain biodiversity in agricultural landscapes (Fisher et al., 2009). A more integrative approach is needed to understand the relationships between semi-natural elements and productive landscape elements and thus, to contribute to a more sustainable agriculture.

Among landscape elements, field margins are the narrow perennial, non-cropped strips bordering fields that differ from agriculture land by their ground structure (e.g. a bank) and/or their vegetation structure

\footnotetext{
* Corresponding author at: INRA, UMR 0980 BAGAP, CS 84215, 35042 Rennes Cedex, France.

E-mail address: audrey.alignier@inra.fr (A. Alignier).

${ }^{1}$ Audrey Alignier and Didier Le Cœur are the two first authors.
} 
(from herbaceous vegetation to bushes and trees or combinations) (Fig. A.1 in Supplementary material). They are important for maintaining biodiversity and associated ecosystem services (Kleijn and Verbeek, 2000; Olson and Wäckers, 2007). Field margins can benefit crop growth by serving as windbreak if planted with trees (Forman and Baudry, 1984), and by reducing soil erosion, floods and pesticide drift (Marshall and Moonen, 2002). Field margin vegetation can also provide resources and refugia for farmland wildlife (Meek et al., 2002). In the last decades, studies were conducted to elucidate drivers of vegetation patterns of field margins. They showed that field margin vegetation is related to environmental conditions, adjacent land use, landscape context and, management practices and their history (de Blois et al., 2002; Le Coeur et al., 2002; Marshall and Moonen, 2002; Alignier and Baudry, 2015). Despite the effort made to prioritize the drivers of vegetation dynamics (e.g. de Blois et al., 2002) and reduce their number in models (e.g. Schippers and Joenje, 2002), models still remain too complex for most agricultural professionals and other land managers.

Indicators are simple and operational tools that increase the ability of users to describe complex phenomena or systems (Girardin et al., 2000). They are key tools for assessing the effects of agricultural management on biodiversity and environment (van der Werf and Petit, 2002) in the perspective of agricultural sustainability. Frequently used indicators are based upon physical or landscape descriptors. Feld et al. (2009) pinpointed that efforts should be made for the development of indicators based upon biological (e.g. species richness) and functional (e.g. species traits) attributes. But, such indicators are generally based upon an exhaustive view of the identity of species in communities such as total species richness of plants, number of rare and/or endangered species (e.g. Alard et al., 1994; Matthews et al., 2009), information which is often laborious and time intensive to collect for non-expert users. To overcome these limitations, the development of simple indicators based upon biological attributes and enabling users to assess the complexity and multifaceted components of biodiversity remains an issue.

In agricultural landscapes, grasslands have received particular attention for the development of indicators (e.g. Alard et al., 1994; Pervanchon et al., 2002; Lewis et al., 2014). Indicators based on species composition or traits have been developed (Wittig et al., 2006) to infer their grazing regime (Höft et al., 2010), their ecological and agronomical values (Plantureux et al., 2010), and their fodder productivity (Duru et al., 2012). By comparison, other semi-natural habitats like field margins received far less attention.

In this paper, we present a flora-based indicator, Ecobordure ('Eco' for ecology and 'bordure' for field margin, in French) designed to describe vegetation patterns of field margin and to infer on local drivers leading to these patterns. By designing Ecobordure, we target agricultural teachers and advisers who seek for tools to increase awareness of agricultural students and farmers and help them to learn about biodiversity patterns and their drivers, i.e. management practices. Doing so, advisers work to increase farmers' ability to identify and develop management practices favorable to vegetation diversity of field margins. Ecobordure was built from a list of 31 reference species, easyto-recognize and representative of the whole vegetation community encountered in field margins typical of bocage regions with oceanic climate and acidic soils. The suitability of Ecobordure as proxy of vegetation drivers of field margins was tested. In a standard scientific concern, the elaboration of the indicator has undergone a validation process at each stage of its development, i.e. design and output validation sensu Bockstaller and Girardin (2003). Finally, some information about the indicator use and appropriation by end-users is provided.

\section{Material and methods}

\subsection{Rationale of Ecobordure}

Ecobordure is an indicator empirically designed and validated to

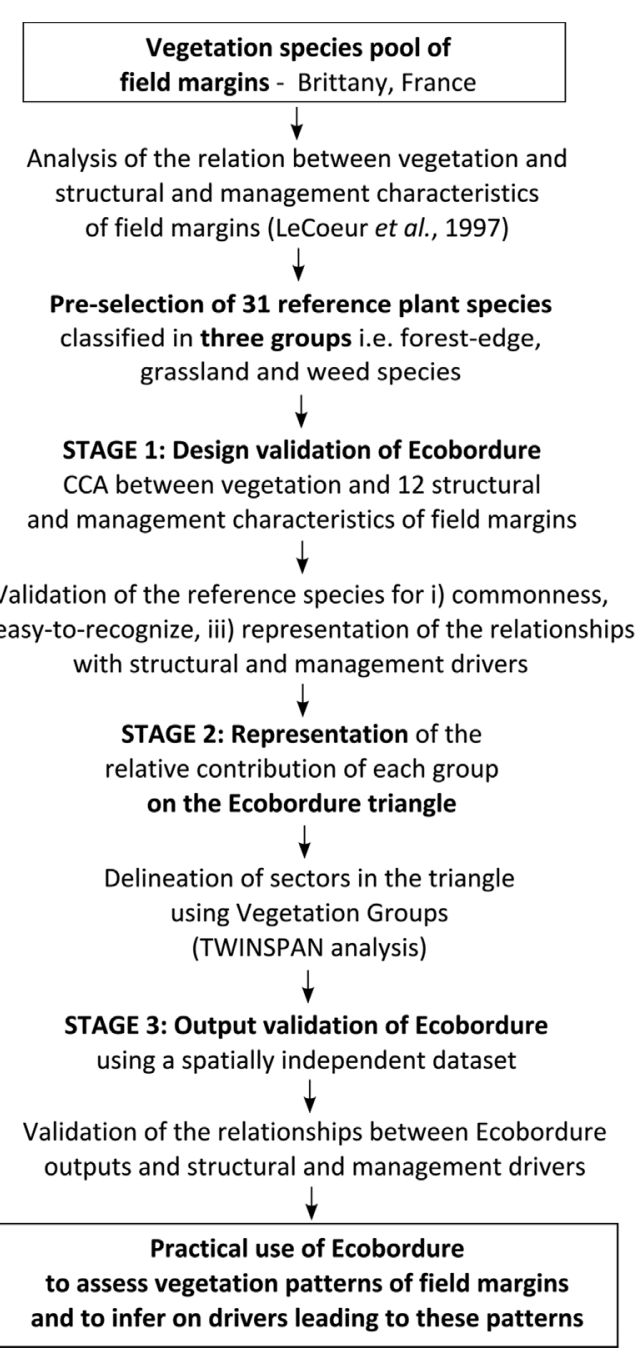

Fig. 1. Framework for the design and validation of Ecobordure.

describe vegetation patterns of field margins in bocage regions, on acidic to neutral soil, with temperate oceanic climate. Ecobordure is based upon the presence of 31 reference herbaceous species classified into three complementary species groups, i.e. forest-edge, grassland and weed species. The choice to consider only the presence/absence of species was motivated by arguments of minimizing errors in the estimation of plant abundance between users and reducing the time costs of implementation. By this way, all Ecobordure users should find the same results. Each species group is made up of plants with similar life history traits and ecological attributes. The three groups provide distinct responses to structural (e.g. presence of trees on field margins) and management (e.g. crop rotation in the adjacent field, management intensity) drivers. Interpretation of Ecobordure outputs allows inference on the potential drivers leading to observed patterns. Fig. 1 presents the main stages of the Ecobordure design and validation.

\subsection{Study area for the Ecobordure design}

The fieldwork was conducted in Zone Atelier Armorique, a Long Term Ecological Research (LTER) site in northern Brittany, France $\left(48^{\circ} 36^{\prime} \mathrm{N}, 1^{\circ} 32^{\prime} \mathrm{W}\right)$. The climate is temperate oceanic with close to $740 \mathrm{~mm}$ of annual precipitation. The bedrock is either granite (southern part of the study area) or shale with loam deposits of variable depth. The $\mathrm{pH}$ of soils ranges from 6 (on granite bedrock) to 7. The annual precipitation ranges from 700 to $800 \mathrm{~mm}$ to $800-900 \mathrm{~mm}$ for higherlying areas on granite bedrock. The study area is located in a region 


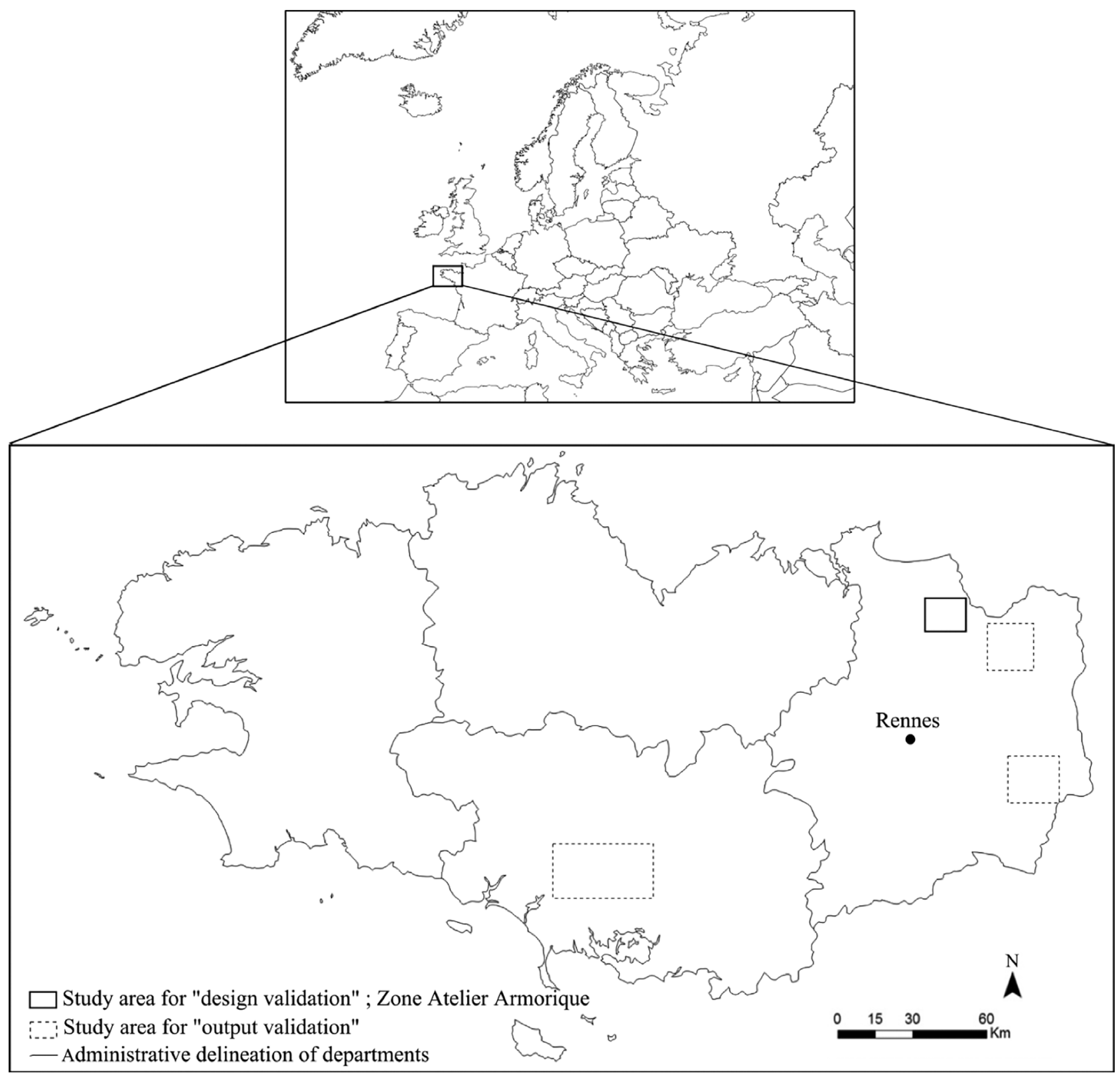

Fig. 2. Location of the study areas for the design (Stage 1) and the output validation (Stage 3) of Ecobordure.

where the dominant agriculture is mixed dairy farming, with annual crops (mostly winter cereals and maize), and temporary and permanent grasslands being bordered by a diversity of field margins, from herbaceous strips to hedgerows, and interspersed by woodlands (Fig. 2).

\subsection{Stage 1: validation of the Ecobordure design}

First of all, relationships between vegetation composition of field margins and 17 structural (e.g. shrub and tree cover) and management (e.g. herbicide spraying, adjacent land cover) drivers were examined through a Canonical Correspondence Analysis (CCA) (for details see Le Coeur et al., 1997). From this previous work, 31 common species were selected according to their i) frequency of occurrence (neither rare nor too frequent), ii) ability to be recognized and determined, iii) ability to reflect variability of the whole community, iv) ability to reflect relationships between vegetation and structural and management characteristics of field margins, i.e. their high contribution to the two first axes of the CCA. These species (Table 1 ) were mainly dicots $(\mathrm{N}=25)$ as their identification by non-experts is said to be easier than monocots
(Höft et al., 2010). Regarding our expertise of regional agricultural landscapes, ecological attributes and traits of species (Le Coeur et al., 1997, 2002), we distinguished three species groups i.e., forest-edge species (11 species), grassland species (10 species) and weed species (10 species; Table 1 ).

To support and validate the selection of the 31 reference plant species ("design validation" sensu Bockstaller and Girardin, 2003), we performed a similar approach to the previous one (Le Coeur et al., 1997). A total of 111 field margins were surveyed in the same study area in 2004. Herb layer vegetation was sampled in $25 \mathrm{~m}$ long quadrats (one quadrat per field margin) placed in the middle of the field margin to avoid edge effects with other field margins. Sampled field margins differed in their structure (presence or not of a ditch, a tree layer, a shrub layer; Fig. A.1 in Supplementary material). To incorporate local heterogeneity in field margin structure and management, the whole width of field margins was sampled. Presence of species was noted and species were identified according to Flora Europaea (Tutin et al., 1993). Field work was carried out from May to July 2004. Concomitantly to vegetation surveys, information about 12 structural and management 
Table 1

List of the 31 reference species of Ecobordure and their values for ecological traits.

\begin{tabular}{|c|c|c|c|c|c|c|c|c|c|}
\hline Group & Species & Code & Life form & EIV-L & EIV-F & EIV-N & EIV-R & CSR strategy & Simplified CSR strategy* \\
\hline Grassland & Anthoxanthum odoratum & ANOD & Monocot & 7 & 6 & 4 & 3 & SR/CSR & $\mathrm{S}$ \\
\hline Forest-edge & Angelica sylvestris & ANSY & Dicot & 7 & 8 & 6 & 5 & $\mathrm{C} / \mathrm{CR}$ & $\mathrm{C}$ \\
\hline Weed & Bromus sterilis & BRST & Monocot & 7 & 5 & 8 & 7 & $\mathrm{R} / \mathrm{CR}$ & $\mathrm{R}$ \\
\hline Weed & Calystegia sepium & CASS & Dicot & 7 & 8 & 7 & 7 & $\mathrm{C} / \mathrm{CR}$ & $\mathrm{C}$ \\
\hline Weed & Cirsium arvense & CIAR & Dicot & 8 & 6 & 7 & 6 & $\mathrm{C}$ & $\mathrm{C}$ \\
\hline Forest-edge & Conopodium majus & COMX & Dicot & 6 & 5 & 5 & 5 & S/CSR & $S$ \\
\hline Grassland & Cruciata laevipes & CRLA & Dicot & 6 & 5 & 7 & 5 & CSR & CSR \\
\hline Forest-edge & Digitalis purpurea & DIPP & Dicot & 6 & 6 & 4 & 5 & $\mathrm{CR} / \mathrm{CSR}$ & $\mathrm{CR}$ \\
\hline Weed & Epilobium tetragonum & EPTT & Dicot & 6 & 7 & 5 & 5 & - & - \\
\hline Weed & Fumaria muralis & FUMM & Dicot & 7 & 5 & 6 & 6 & $\mathrm{R}$ & $\mathrm{R}$ \\
\hline Weed & Galium aparine & GAAP & Dicot & 6 & 6 & 7 & 8 & $\mathrm{CR}$ & $\mathrm{CR}$ \\
\hline Forest-edge & Hedera helix & HEHH & Dicot & 4 & 5 & 7 & 6 & SC & SC \\
\hline Grassland & Holcus lanatus & HOLA & Monocot & 7 & 6 & 6 & 5 & CSR & CSR \\
\hline Weed & Juncus bufonius & JUBU & Monocot & 7 & 7 & 6 & 5 & $\mathrm{R}$ & $\mathrm{R}$ \\
\hline Weed & Lapsana communis & LACC & Dicot & 6 & 4 & 7 & 7 & $\mathrm{R} / \mathrm{CR}$ & $\mathrm{R}$ \\
\hline Grassland & Leucanthemum vulgare & LEVU & Dicot & 8 & 4 & 7 & 4 & $\mathrm{CR} / \mathrm{CSR}$ & $\mathrm{CR}$ \\
\hline Forest-edge & Lonicera periclymenum & LOPP & Dicot & 5 & 6 & 5 & 5 & SC & SC \\
\hline Weed & Poa annua & POAN & Monocot & 7 & 5 & 6 & 7 & $\mathrm{R}$ & $\mathrm{R}$ \\
\hline Forest-edge & Potentilla sterilis & POST & Dicot & 5 & 5 & 5 & 5 & $\mathrm{~S}$ & $\mathrm{~S}$ \\
\hline Forest-edge & Polypodium vulgare & POVU & Pterido & 5 & 5 & 4 & 3 & $\mathrm{~S}$ & $\mathrm{~S}$ \\
\hline Grassland & Ranunculus acris & RAAA & Dicot & 7 & 6 & 6 & 4 & CSR & CSR \\
\hline Grassland & Ranunculus repens & RARE & Dicot & 6 & 7 & 6 & 7 & CR & CR \\
\hline Grassland & Rumex acetosa & RUAC & Dicot & 7 & 5 & 5 & 4 & CSR & CSR \\
\hline Weed & Sonchus asper & SOAY & Dicot & 7 & 5 & 7 & 6 & $\mathrm{R} / \mathrm{CR}$ & $\mathrm{R}$ \\
\hline Forest-edge & Stellaria holostea & STHO & Dicot & 5 & 5 & 6 & 6 & CSR & CSR \\
\hline Grassland & Taraxacum officinale agg. & TAOF & Dicot & 7 & 5 & 7 & 6 & $\mathrm{R} / \mathrm{CSR}$ & $\mathrm{R}$ \\
\hline Forest-edge & Teucrium scorodonia & TESS & Dicot & 6 & 4 & 4 & 3 & CSR & CSR \\
\hline Grassland & Trifolium repens & TRRR & Dicot & 7 & 5 & 6 & 6 & $\mathrm{CR} / \mathrm{CSR}$ & CR \\
\hline Grassland & Urtica dioica & URDI & Dicot & 6 & 6 & 7 & 8 & $\mathrm{C}$ & $\mathrm{C}$ \\
\hline Forest-edge & Veronica chamaedrys & VECC & Dicot & 6 & 5 & 6 & 5 & $\mathrm{~S} / \mathrm{CSR}$ & $\mathrm{S}$ \\
\hline Forest-edge & Viola riviniana & VIRI & Dicot & 6 & 5 & 5 & 4 & $\mathrm{~S}$ & $\mathrm{~S}$ \\
\hline
\end{tabular}

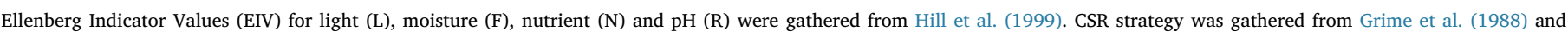
simplified (*) for further statistical analyses.

Table 2

Structural and management characteristics of field margins used as explanatory variables in the Canonical Correspondence Analysis (CCA) for the design validation of Ecobordure. * indicates variables used for the output validation of Ecobordure.

\begin{tabular}{|c|c|c|c|}
\hline Variable & Code & $\begin{array}{l}\text { Type of } \\
\text { variable }\end{array}$ & Values or unit \\
\hline \multicolumn{4}{|l|}{ Structure of boundary } \\
\hline Presence of trees * & ST & binary & $0:$ absence; $1:$ presence \\
\hline Presence of shrubs & SS & binary & $0:$ absence; $1:$ presence \\
\hline Presence of a ditch & SD & binary & $0:$ absence; 1 : presence \\
\hline Presence of a bank & SB & binary & $0:$ absence; 1 : presence \\
\hline \multicolumn{4}{|l|}{ Cover } \\
\hline Tree cover & $\mathrm{CT}$ & ordinal & 0-5 (Tansley's coefficients) \\
\hline Shrub cover & CS & ordinal & 0-5 (Tansley's coefficients) \\
\hline \multicolumn{4}{|l|}{ Width } \\
\hline Inter-fields width & WIF & continuous & meters \\
\hline Canopy width & WT & continuous & meters \\
\hline \multicolumn{4}{|l|}{ Management } \\
\hline $\begin{array}{l}\text { Rotation type of the } \\
\text { adjacent field * }\end{array}$ & MR & categorical & $\begin{array}{l}\text { AC: only annual crops; TG: } \\
\text { includes temporary } \\
\text { grassland; PG: permanent } \\
\text { grassland }\end{array}$ \\
\hline $\begin{array}{l}\text { Non-selective herbicide } \\
\text { treatments on field } \\
\text { margins * }\end{array}$ & MC & categorical & $\begin{array}{l}0 \text { : no treatment; } 1 \text { : rare; } 2 \text { : } \\
\text { irregular; } 3 \text { : at least once per } \\
\text { year }\end{array}$ \\
\hline $\begin{array}{l}\text { Mechanical operations on } \\
\text { field margins * }\end{array}$ & MM & categorical & $\begin{array}{l}0: \text { no treatment; } 1: \text { rare; } 2 \text { : } \\
\text { irregular; } 3 \text { : at least once per } \\
\text { year }\end{array}$ \\
\hline $\begin{array}{l}\text { Livestock accessibility to } \\
\text { field margins* }\end{array}$ & ML & categorical & $\begin{array}{l}0: \text { no access; } 1 \text { : limited } \\
\text { access to grazing; } 2: \text { large } \\
\text { access to grazing }\end{array}$ \\
\hline
\end{tabular}

characteristics of field margins, i.e. the presence of shrub and tree layers, width and management of field margins (i.e. non-selective herbicide treatment) as well as crop succession in the adjacent fields was gathered through farmers' interviews (Table 2).

Canonical Correspondence Analysis (Ter Braak, 1987) was performed to obtain an overview of the relationship between vegetation composition and structural and management characteristics of field margins. CCA constructs linear combinations (axes) of environmental variables along which the distribution of the species are maximally separated. All species $(\mathrm{N}=245)$ were analyzed using their presence/ absence and rare species were not down-weighted. Statistical significance of the relationship was tested using Monte Carlo simulations with 999 permutations. We visually checked whether the 31 selected reference species were representative of the whole community. We tested for significant differences between the three species groups (forest-edge, grassland and weed species) according to their position along the two first CCA axes, using ANOVA tests. We then identified relationships between the three species groups and characteristics of field margins to elaborate a table of "potential drivers". The constrained ordination was performed using the package vegan (Oksanen et al., 2015) from R 3.0.2 (R Development Core Team, 2014).

\subsection{Stage 2: representation of field margins in the Ecobordure triangle}

We proposed a graphical representation in the form of a triplot diagram, the "Ecobordure triangle". The sides of the triangle represent the axes of notation of the relative percentages of each species group. From 2004 vegetation surveys, we registered the presence/absence of each of the 31 reference species in relevés. Each reference species pertaining to a species group (i.e. forest-edge, grassland and weed species), we then calculated the relative percentage of each group (i.e. scores) such as the total species richness over all the three groups corresponded to $100 \%$. By doing this, we defined vegetation pattern of each field margin from the relative weight of each group in the whole 
referential of species. Vegetation pattern of one field margin is then represented in the Ecobordure triangle at the crossing point of the projection of its scores.

With this method, the representation of a set of field margins is a cloud of points in the Ecobordure triangle, each point representing one field margin. As we considered that a visual qualitative description of this cloud of points was not sufficient to support interpretation and to compare field margins in a robust way, we delimited the Ecobordure triangle in sectors.

From 2004 vegetation surveys (111 field margins and 245 plant species surveyed), we classified field margins according to their whole vegetation composition using a TWINSPAN analysis (Hill, 1979). TWINSPAN is a hierarchical divisive method which provides a classification of samples based on their taxonomic composition outlining the indicator species pertaining to each dichotomic group division. The optimal cluster number, i.e. emergent groups, was determined through visual inspection of the cluster dendrogram with attention paid to maintaining sufficient number of vegetation relevés per group. Ten Vegetation Groups (VG) were obtained from TWINSPAN. From our expertise and the comparison of vegetation groups according to their homogeneity in species composition and ecological attributes (i.e. Ellenberg values, CSR strategy), we pooled the $10 \mathrm{VG}$ in seven sectors (1 or 2 VG per sector): three "reference" sectors characterized by homogeneous vegetation and ecological attributes (F: forest-edge, G: grassland and W: weed) and four intermediate sectors with mixed vegetation (FG, Fw, Gw, FGw).

To delimit the seven sectors in the Ecobordure triangle, we studied the variation in the distribution of the relative percentage of forestedge, weed and grassland groups within each Vegetation Group $(\mathrm{N}=10)$. Thresholds were positioned according to the first and third quartile of the distribution, with a particular attention paid to extreme, i.e. minimum and maximum, values. In cases where quartiles were insufficient to discriminate thresholds due to overlap in the distribution of percentages between VG, we considered the median value as the limit. Hence, sectors represent distinct mesologic and/or ecological conditions defined from exhaustive vegetation composition.

\subsection{Stage 3: validation of the Ecobordure outputs—study area and method}

We tested the suitability of Ecobordure to reveal potential drivers of vegetation patterns by testing the relevance of the representation of each field margin in the Ecobordure triangle. We compared the proportion of field margins per sector as a function of structural and management variables with Chi-squared tests. We used a spatially independent dataset, outside the Zone Atelier Armorique. We performed vegetation relevés (for details on protocol, see Stage 2) in 2009 on 279 field margins located in eastern and southern Brittany, France (Fig. 2). Field margins are located either on granite bedrock or on altered shale. The soil pH ranges from 5.5 to 6.5 . The overall climate is oceanic but with annual precipitations spanning from 600 to $1000 \mathrm{~mm}$. We registered structural (ST) and management (MR, MC, MM and ML) characteristics of field margins (see Table 2 for the code of variables) that are known to affect field margin vegetation (Le Coeur et al., 1997; Marshall and Moonen, 2002; Alignier and Baudry, 2015). These characteristics were registered through field observations and farmers' interviews.

All statistical analyses were carried out with the $R$ software ( $R$ Development Core Team, 2014).

\section{Results}

\subsection{Design validation of Ecobordure (Stage 1)}

The relevés were significantly separated along axes correlated to structure and management of the field margins in the CCA (Monte-Carlo test, $\mathrm{p}<0.05$ ). The total variation explained by the first

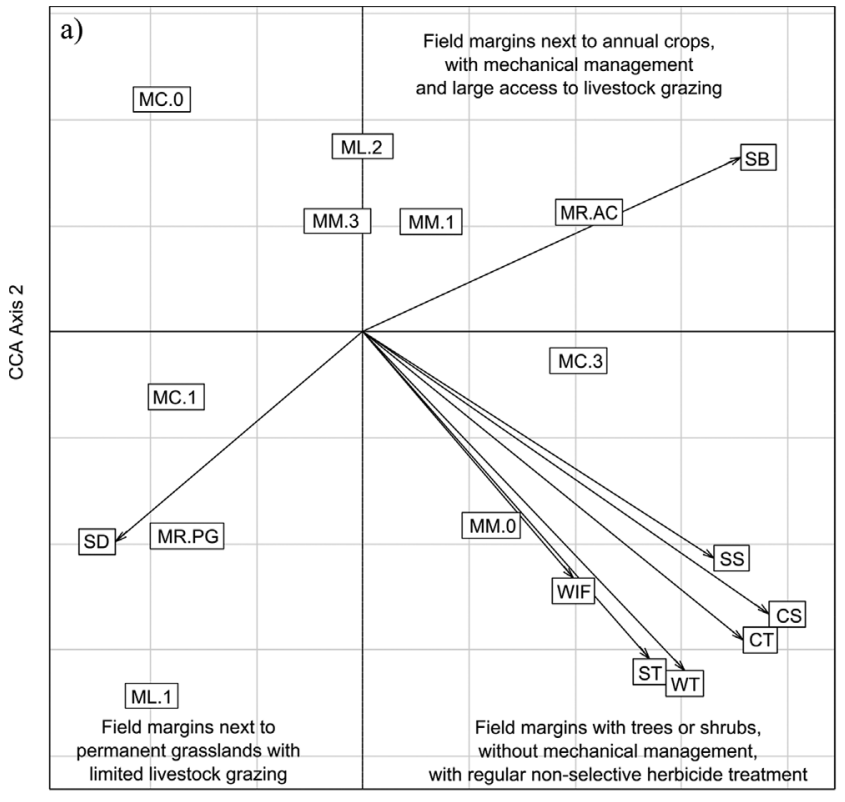

CCA Axis 1

b)
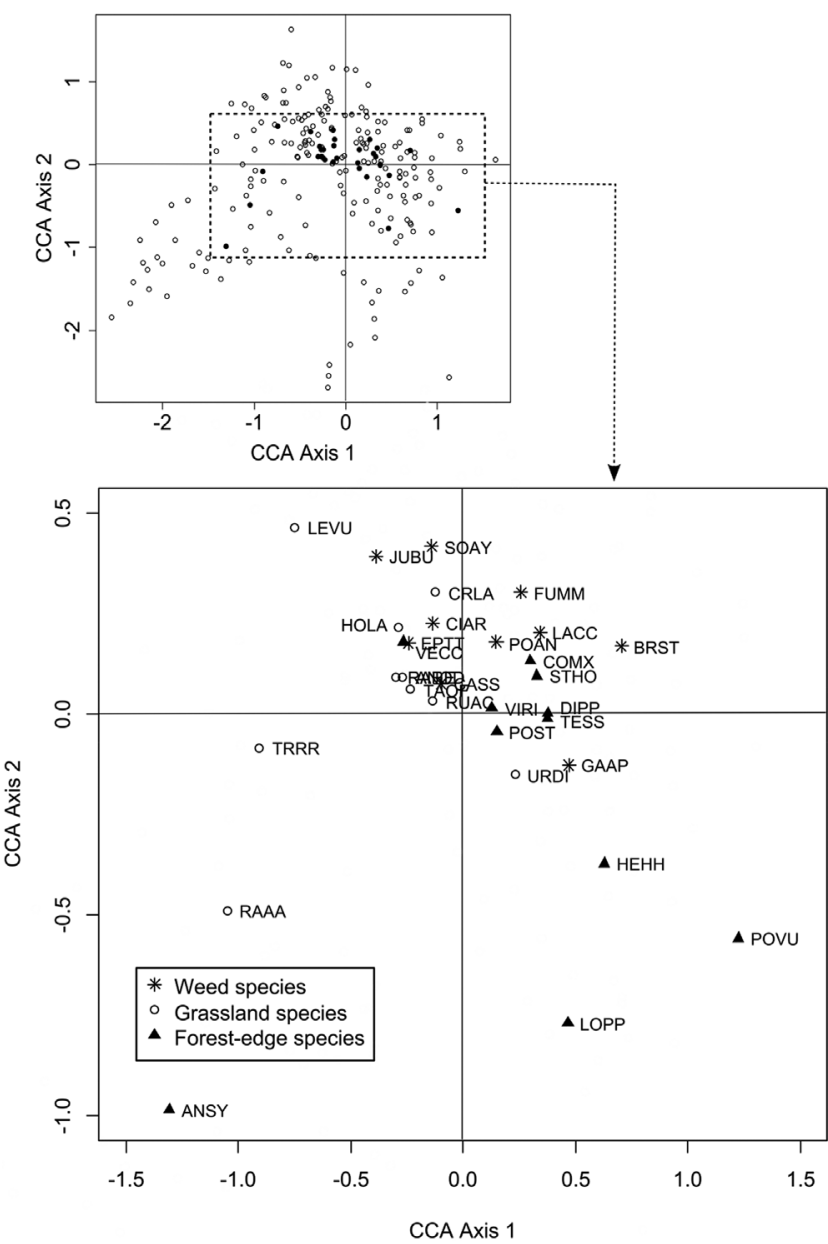

Fig. 3. Canonical Correspondence Analysis (CCA) ordination diagram. For clarity, a) structural and agricultural variables $(\mathrm{N}=12)$ and b) plant species $(\mathrm{N}=245)$ are represented in separate diagrams. The position of the 31 reference plant species (black circles) among the whole community (white circles) along the two first CCA axes is highlighted. See Table 2 for the code of variables and Appendix A for the code of species. 
four axes was $10 \%$ for the species data and $45 \%$ for the species-environment data. Tree cover and shrub cover had the strongest correlations to the first canonical axis $(r=0.72, p<0.001$ and $r=0.78$, $\mathrm{p}<0.001$ respectively) and canopy width to the second canonical axis ( $\mathrm{r}=-0.68, \mathrm{p}<0.001)$.

The biplot of the CCA (Fig. 3) separated species of woody margins (with shrubs and/or with trees, SS and ST) associated with high canopy width (WT), no mechanical management (MM.0), with and regular herbicide treatment (MC.3) like Bromus sterilis, Crataegus monogyna, Geranium robertianum, Umbilicus rupestris from those of non woody margins, e.g. Plantago lanceolata, Ajuga reptans, Trifolium repens, Lotus uliginosus. Species of margins with a ditch (SD) (e.g. Oenanthe crocata, Filipendula ulmaria, Juncus acutiflorus, J. effusus) were positively associated with limited livestock grazing (ML.1) and permanent grasslands (MR.PG) and were separated from species present on margins with a bank (SB) (e.g. Galium mollugo, Rumex acetosella, Jasione montana, Hypericum perforatum) (Fig. 3a).

Regarding the 31 reference species, their distribution along the two first CCA axes was representative of the whole community (Fig. 3b). The distribution of the three species groups (forest-edge, grassland and weed species) was significantly different along CCA axis 1 (ANOVA, $\mathrm{F}=4.52, \mathrm{p}=0.019$ ) and CCA axis 2 (ANOVA, $\mathrm{F}=5.32, \mathrm{p}=0.011$ ). Their distribution was consistent with structural and management factors: forest-edge species, on the right of the biplot, were associated with margins with tree (ST) and shrub cover (SS), whereas grassland species were associated with margins having a ditch (SD) and rare herbicide treatment (MC.1). Weed species, mainly on the top of the biplot, were associated with field margins next to annual crops (MR.AC) and frequently mechanically managed (MM.3) (Fig. 3b). From this analysis, we elaborate a table linking species groups and their potential drivers (Table 3 ).

\subsection{Delimitation of the Ecobordure triangle sectors (Stage 2)}

Ten vegetation groups were identified according to the TWINSPAN analysis (Table A.1 in Supplementary material). Each VG contained near $30 \%$ of reference species (Table 4). VG1, VG2 and VG3 were homogeneous assemblages of light-requiring species (with the highest Ellenberg indicator values for light) and their vegetation composition, with more than one third of monocots, was representative of 'grassland' field margins (sector G in the Ecobordure triangle; Table 4). VG2 had a high proportion of annual species (22.9\%) and high nitrogen Ellenberg indicator value (Table 4). Thus, VG2 was assigned to an intermediate sector between 'grassland' and weedy field margins (Gw). VG4 was characterized by grassland and forest edge vegetation and was considered as representative of a mixed sector between 'grassland' and 'forest-edge' field margins (FG). The most frequent species of VG5 and VG6 were undergrowth vegetation which requires shade and fresh conditions, i.e. Umbilicus rupestris and Polypodium vulgare (Table A.1 in Supplementary material). VG6 had high frequency of ruderal species like Bromus sterilis and displayed a shift towards stress-tolerant Grime strategy both revealing more disturbed conditions (Table 4). Thus, VG5 was assigned to a sector representing 'forest-edge' margins (F) and VG6 to a 'forest-edge'-'weed' sector (Fw).Compared to VG5 and VG6, VG7 had higher Ellenberg value for light and nitrogen (Table 4). VG7 had the lowest species richness of the herb layer. Its composition was reduced to few annual and nitrophilous species like Galium aparine and perennial competitive grasses like Arrhenatherum elatius ssp. bulbosus (Table A.1 in Supplementary material). So, VG7 characterized very mixed field margins and was assigned to a 'forest-edge'-'grassland''weed' sector (FGw). VG9 and VG10 had the highest proportion of annual species (26.6\% and 36\%, respectively) and ones of the highest nitrogen Ellenberg indicator values (5.5 and 6.4, respectively) (Table 4). Both VG9 and VG10 had species representative of ruderal habitat like fallow (e.g. Elymus repens, Hypericum perforatum, Senecio jacobae) and crop (e.g. Stellaria media, Geranium dissectum, Senecio vulgaris) with variation of frequencies. Thus, VG9 and VG10 characterized weedy field margins (sector W). VG8 with ruderal plant assemblages was close to VG9 and VG10. VG8 contained species from grassland and pre-forest hems and was assigned as VG7 to the intermediate sector FGw.

Fig. 4 provides an example of the definition of thresholds position for the weedy sector (W). VG9 and VG10, characteristics of the weedy sector (W), had their proportion of weed reference species varying from 25 to $100 \%$ (Table A.2 in Supplementary material). The first quartile of their distribution reached $42.9 \%$ and $38.5 \%$ respectively. Therefore, the upper limit of the weedy sector (W) was placed at $40 \%$. No-weedy sectors (F, G, FG) represented by VG1, VG3, VG4 and VG5, had a proportion of weedy species varying from $0 \%$ to $36.4 \%$, with a third quartile not exceeding $31 \%$ and median values lower than $25 \%$ (Table A.2 in Supplementary material). Thus, we chose to position the lower limit at $25 \%$ (Fig. 4). We repeated this method for the proportion of forest-edge and grassland reference species leading to the final Ecobordure triangle with sectors (Fig. 5).

\subsection{Output validation of Ecobordure (Stage 3)}

The proportion of field margins in each sector of the Ecobordure triangle varied significantly according to structural and management variables with exception of the mechanical treatment (Table 5). We showed that the most forested sectors (F, Fw, FG) were significantly associated with field margins having tree and/or shrub cover and no or low non-selective herbicide treatment. 'Grassland' sectors (G, Gw) were significantly associated with non-woody field margins, no or low nonselective herbicide treatment, high livestock accessibility and rotation including permanent or temporary grassland (Table 5). Field margins of the weedy sector (W) showed high disturbance from both annual crop rotation (e.g. frequent tillage, fertilizers drift) and non-selective herbicide treatment. The intermediate sector (FGw) did not show clear pattern with quite homogeneous distribution of field margins according to their structural and management characteristics (Table 5). These results were concordant with Table 3 . We thus validated the relevance of sectors to report on structural and management drivers of vegetation patterns.

\section{Discussion}

A large number of indicators are currently available for agricultural

Table 3

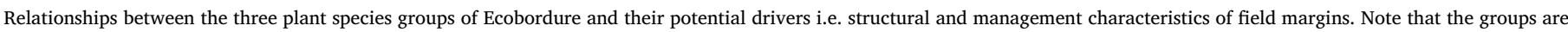
representative of 'extreme' sectors (F, G, W) in the Ecobordure triangle. Potential drivers of intermediate sectors (FG, Fw, Gw, FGw) are combination of those of extreme sectors.

\begin{tabular}{|c|c|c|c|}
\hline Code & Species group & Description of the vegetation type & Potential drivers \\
\hline $\mathrm{F}$ & Forest-edge & perennial; shade-requiring; psychrophilous ${ }^{\mathrm{a}}$ & former or current presence of trees; no or low mechanical/herbicide management \\
\hline G & Grassland & perennial; light-requiring; high proportion of monocots & regular mechanical management (mowing, shredding); grazing by cattle \\
\hline W & Weed & annual/biennal; ruderal; nitrophilous & intensive mechanical or non-selective herbicide treatment leading to bare soil \\
\hline
\end{tabular}

${ }^{\text {a }}$ Species that require fresh conditions to grow and survive. 
Table 4

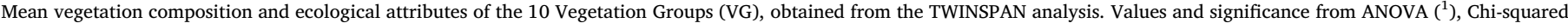
$\left({ }^{2}\right)$ and Kruskal-Wallis $\left({ }^{3}\right)$ tests for the distinction of the 10 VG are given. Different letters indicate significant differences at $P=0.05$.

\begin{tabular}{|c|c|c|c|c|c|c|c|c|c|c|c|c|c|}
\hline & Value & $\mathrm{P}$ & ddl & $\begin{array}{l}\text { VG1 } \\
\mathrm{n}=6\end{array}$ & $\begin{array}{l}\text { VG2 } \\
n=4\end{array}$ & $\begin{array}{l}\text { VG3 } \\
\mathrm{n}=4\end{array}$ & $\begin{array}{l}\text { VG4 } \\
\mathrm{n}=11\end{array}$ & $\begin{array}{l}\text { VG5 } \\
\mathrm{n}=21\end{array}$ & $\begin{array}{l}\text { VG6 } \\
\mathrm{n}=11\end{array}$ & $\begin{array}{l}\text { VG7 } \\
\mathrm{n}=25\end{array}$ & $\begin{array}{l}\text { VG8 } \\
\mathrm{n}=10\end{array}$ & $\begin{array}{l}\text { VG9 } \\
\mathrm{n}=13\end{array}$ & $\begin{array}{l}\text { VG10 } \\
\mathrm{n}=6\end{array}$ \\
\hline \multicolumn{14}{|l|}{ Species richness ${ }^{1}$} \\
\hline Herb layer & 3.1 & $<0.01$ & 9 & $31.8^{\mathrm{bd}}$ & $17.3^{\mathrm{ab}}$ & $28.5^{\text {bd }}$ & $37.4^{\mathrm{d}}$ & $25.6^{\mathrm{bc}}$ & $28.2^{\text {bd }}$ & $15.5^{\mathrm{a}}$ & $31.8^{\mathrm{cd}}$ & $21.6^{\mathrm{ab}}$ & $25.7^{\text {abd }}$ \\
\hline Tree/shrub layer & 8.3 & $<0.001$ & 9 & $0.7^{\mathrm{a}}$ & $0.3^{\mathrm{a}}$ & $0.8^{\mathrm{a}}$ & $1.5^{\mathrm{a}}$ & $5.5^{\mathrm{c}}$ & $5.2^{\mathrm{bc}}$ & $2.9^{\mathrm{ab}}$ & $2.1^{\mathrm{a}}$ & $2.5^{\mathrm{ab}}$ & $2.2^{\mathrm{ab}}$ \\
\hline \multicolumn{14}{|c|}{ Growth form (herb layer) $^{1}$} \\
\hline$\%$ Dicots & 3.5 & $<0.001$ & 9 & $65.1^{\mathrm{ab}}$ & $64.7^{\mathrm{ab}}$ & $61.2^{\mathrm{ab}}$ & $70.0^{\mathrm{ab}}$ & $69.9^{\mathrm{ab}}$ & $77.5^{\mathrm{b}}$ & $62.1^{\mathrm{a}}$ & $73.9^{\mathrm{b}}$ & $67.2^{\mathrm{ab}}$ & $66.2^{\mathrm{ab}}$ \\
\hline$\%$ Monocots & 3.7 & $<0.001$ & 9 & $33.2^{\mathrm{ab}}$ & $35.3^{\mathrm{ab}}$ & $38.8^{\mathrm{b}}$ & $27.8^{\mathrm{ab}}$ & $26.3^{\mathrm{ab}}$ & $19.4^{\mathrm{a}}$ & $32.9^{\mathrm{b}}$ & $22.9^{\mathrm{ab}}$ & $28.6^{\mathrm{ab}}$ & $31.7)^{\mathrm{ab}}$ \\
\hline$\%$ Ferns & 3.1 & $<0.01$ & 9 & $1.7^{\mathrm{a}}$ & $0^{\mathrm{a}}$ & $0^{\mathrm{a}}$ & $2.2^{\mathrm{a}}$ & $3.8^{\mathrm{a}}$ & $3.2^{\mathrm{a}}$ & $4.9^{\mathrm{a}}$ & $3.2^{\mathrm{a}}$ & $4.2^{\mathrm{a}}$ & $2.1^{\mathrm{a}}$ \\
\hline \multicolumn{14}{|c|}{ Life-span types (herb layer) ${ }^{1}$} \\
\hline$\%$ Annuals & 7.6 & $<0.001$ & 9 & $9.8^{\mathrm{a}}$ & $22.9^{\text {ac }}$ & $6.5^{\mathrm{a}}$ & $11.3^{\mathrm{a}}$ & $13.1^{\mathrm{a}}$ & $21.2^{\mathrm{ab}}$ & $13.3^{\mathrm{a}}$ & $17.9^{\mathrm{ab}}$ & $26.6^{\mathrm{bc}}$ & $36^{\mathrm{c}}$ \\
\hline \multicolumn{14}{|c|}{ CSR strategy (herb layer - Proportion) ${ }^{2}$} \\
\hline $\mathrm{C}$ & & & & 17 & 10 & 12 & 16 & 18 & 15 & 36 & 16 & 25 & 17 \\
\hline $\mathrm{R}$ & & & & 18 & 34 & 13 & 15 & 16 & 25 & 10 & 21 & 26 & 34 \\
\hline S & & & & 3 & 0 & 14 & 8 & 12 & 12 & 3 & 10 & 4 & 4 \\
\hline CR & 163.8 & $<0.001$ & 63 & 29 & 22 & 16 & 19 & 15 & 18 & 17 & 19 & 15 & 18 \\
\hline SC & & & & 6 & 5 & 3 & 6 & 12 & 9 & 15 & 3 & 5 & 3 \\
\hline SR & & & & 3 & 7 & 4 & 5 & 6 & 4 & 2 & 4 & 2 & 2 \\
\hline CSR & & & & 21 & 19 & 35 & 25 & 18 & 11 & 11 & 21 & 15 & 10 \\
\hline \multicolumn{14}{|c|}{ Ellenberg values (herb layer - Median) ${ }^{3}$} \\
\hline EIV-L & 51.9 & $<0.001$ & 9 & $6.9^{c}$ & $6.9^{\mathrm{bc}}$ & $7^{\mathrm{c}}$ & $6.8^{\mathrm{c}}$ & $6.5^{\mathrm{ab}}$ & $6.4^{\mathrm{a}}$ & $6.6^{\mathrm{abc}}$ & $6.7^{\mathrm{bc}}$ & $6.5^{\mathrm{abc}}$ & $6.8^{\mathrm{bc}}$ \\
\hline EIV-F & 38.8 & $<0.001$ & 9 & $6.8^{\mathrm{c}}$ & $5.8^{\mathrm{bc}}$ & $5.4^{\mathrm{bc}}$ & $5.4^{\mathrm{bc}}$ & $5.3^{\mathrm{ab}}$ & $5.2^{\mathrm{ab}}$ & $5.5^{\mathrm{bc}}$ & $5.2^{\mathrm{ab}}$ & $5^{\mathrm{a}}$ & $5.4^{\mathrm{bc}}$ \\
\hline EIV-N & 37.6 & $<0.001$ & 9 & $5.5^{\mathrm{abc}}$ & $6^{\mathrm{abc}}$ & $5.2^{\mathrm{ab}}$ & $5.3^{\mathrm{ab}}$ & $5.4^{\mathrm{a}}$ & $5.7^{\mathrm{abc}}$ & $5.9^{\mathrm{bc}}$ & $5.2^{\mathrm{ab}}$ & $5.5^{\mathrm{abc}}$ & $6.5^{c}$ \\
\hline EIV-R & 36.9 & $<0.001$ & 9 & $5.4^{\mathrm{bc}}$ & $5.7^{\mathrm{bc}}$ & $5.4^{\mathrm{abc}}$ & $5.3^{\mathrm{abc}}$ & $4.5^{\mathrm{a}}$ & $5^{\mathrm{abc}}$ & $4.9^{\mathrm{abc}}$ & $4.7^{\mathrm{abc}}$ & $5^{\mathrm{abc}}$ & $5.8^{c}$ \\
\hline \multicolumn{14}{|c|}{ Reference species proportion ${ }^{1}$} \\
\hline Forest-edge & 11.5 & $<0.001$ & 9 & $7.5^{\mathrm{b}}$ & $5^{\mathrm{ab}}$ & $15.4^{\mathrm{bc}}$ & $28.4^{\mathrm{bc}}$ & $50.3^{\mathrm{e}}$ & $46.9^{\text {de }}$ & $37.1^{\mathrm{cd}}$ & $36.5^{\mathrm{ce}}$ & $29.5^{\text {acd }}$ & $17.7^{\mathrm{bc}}$ \\
\hline Grassland & 20.9 & $<0.001$ & 9 & $78.3^{\mathrm{e}}$ & $67.3^{\mathrm{de}}$ & $68.8^{\mathrm{de}}$ & $49.4^{\mathrm{cd}}$ & $26.3^{\mathrm{ab}}$ & $21.9^{\mathrm{ab}}$ & $26.2^{\mathrm{ab}}$ & $38.9^{\mathrm{bc}}$ & $17.1^{\mathrm{a}}$ & $30.5^{\mathrm{ac}}$ \\
\hline Weed & 9.7 & $<0.001$ & 9 & $14.3^{\mathrm{a}}$ & $27.7^{\mathrm{ac}}$ & $15.8^{\mathrm{ab}}$ & $22.2^{\mathrm{ab}}$ & $23.4^{\mathrm{a}}$ & $31.2^{\mathrm{ac}}$ & $36.7^{\mathrm{bc}}$ & $24.5^{\mathrm{ab}}$ & $53.4^{\mathrm{d}}$ & $51.7^{\mathrm{cd}}$ \\
\hline All groups & 2.6 & $<0.01$ & 9 & $26.5^{\mathrm{a}}$ & $28.5^{\mathrm{ab}}$ & $28.9^{\mathrm{ab}}$ & $33.6^{\mathrm{ab}}$ & $38.5^{\mathrm{b}}$ & $34.9^{\mathrm{ab}}$ & $36.5^{\mathrm{ab}}$ & $36.3^{\mathrm{ab}}$ & $31.1^{\mathrm{ab}}$ & $31.7^{\mathrm{ab}}$ \\
\hline Sector & & & & G & $\mathrm{Gw}$ & G & FG & $\mathrm{F}$ & Fw & FGw & FGw & $\mathrm{W}$ & $\mathrm{W}$ \\
\hline
\end{tabular}

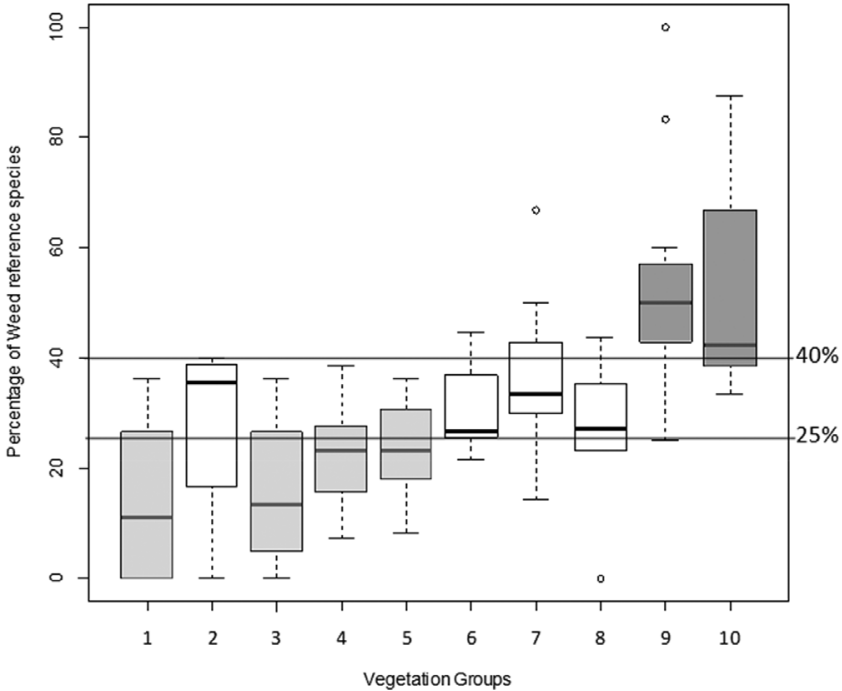

Fig. 4. Distribution of the percentage of weed reference species per field margin according to Vegetation Groups (VG, N = 10). The first quartile of VG9 and VG10 (in dark gray) gives the threshold (i.e. 40\%) for the delimitation of the weedy sector (W), whereas the distribution of non-weedy sectors (F, G, FG) represented by VG1, VG3, VG4, VG5 (in light gray) gives the lower threshold (i.e. $25 \%$ ). In white, the distribution of mix-weedy sectors (Fw, Gw and FGw) represented by VG2, VG6, VG7 and VG8.

stakeholders who need to assess the impact of agriculture on biodiversity (Delbaere, 2003; Bockstaller et al., 2011). But few of them are based upon direct measurements of organisms (see Clergué et al., 2005 for an overview) and enable users to analyze the causal relationships between vegetation patterns and management data (Pywell et al., 2011; Ricou et al., 2014). With Ecobordure, we succeed in developing a simple, efficient and reliable indicator allowing users to describe

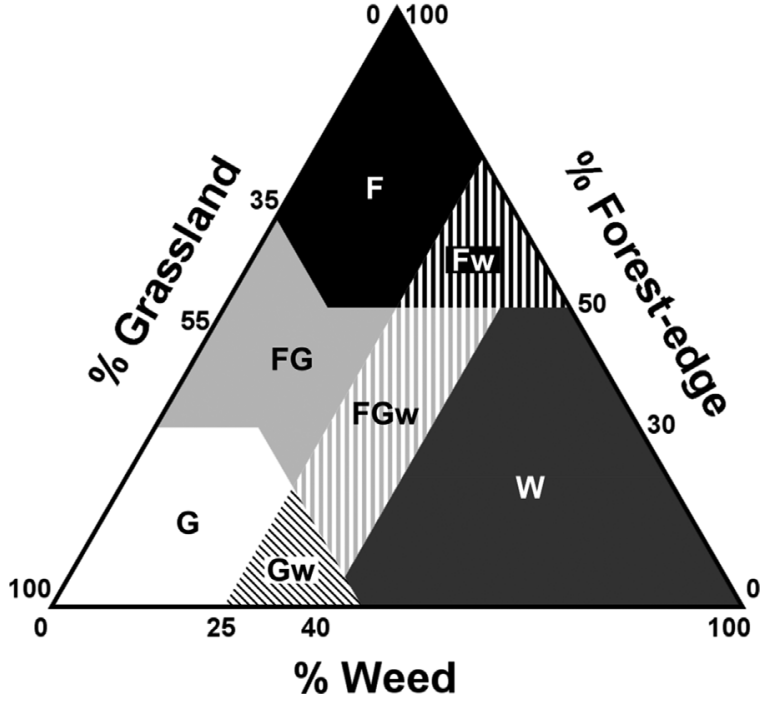

Fig. 5. Representation of the Ecobordure triangle with its seven sectors. F: Forest-edge, G: Grassland, W: Weed.

vegetation patterns of field margins according to seven types, homogeneous or mixed, corresponding to the seven sectors of the triangle.

On the one hand, we showed that Ecobordure is efficient in revealing potential causes of the observed vegetation patterns. For grassland communities, it has been shown that ecological characteristics of plant species help to distinguish between differing land-use disturbance (Garnier et al., 2007). Based upon three complementary species groups with contrasted ecological requirements, Ecobordure can reveal a wide range of potential drivers but also aspects sometimes counter-intuitive. The fact that Ecobordure is validated ensures that 
Table 5

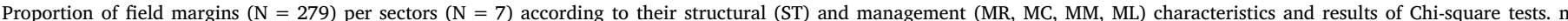
indicates the total number of field margins per sector. For the code of variables, refer to Table 2.

\begin{tabular}{|c|c|c|c|c|c|c|c|c|c|c|c|c|}
\hline \multirow[t]{2}{*}{ Variable } & \multirow[t]{2}{*}{ Value } & \multirow[t]{2}{*}{ Number of field margins } & \multirow[t]{2}{*}{ Test value } & \multirow[t]{2}{*}{ ddl } & \multirow[t]{2}{*}{$P$} & \multicolumn{7}{|c|}{ Proportion (\%) of field margins in each sector } \\
\hline & & & & & & $\mathrm{F}$ & Fw & FG & FGw & G & $\mathrm{Gw}$ & $\mathrm{W}$ \\
\hline ST & 0 & 170 & 71.93 & 6 & $<0.001$ & 3 & 0 & 12 & 13 & 25 & 21 & 26 \\
\hline ST & 1 & 109 & & & & 22 & 11 & 22 & 16 & 6 & 6 & 17 \\
\hline MR & PG & 53 & 56.47 & 12 & $<0.001$ & 15 & 0 & 25 & 9 & 26 & 21 & 4 \\
\hline MR & TG & 188 & & & & 11 & 5 & 16 & 16 & 18 & 13 & 20 \\
\hline MR & AC & 38 & & & & 0 & 8 & 0 & 10 & 5 & 18 & 58 \\
\hline MC & 0 & 71 & 65.46 & 18 & $<0.001$ & 10 & 2 & 18 & 4 & 36 & 22 & 7 \\
\hline MC & 1 & 97 & & & & 16 & 7 & 16 & 18 & 14 & 11 & 19 \\
\hline MC & 2 & 66 & & & & 9 & 3 & 18 & 15 & 15 & 12 & 27 \\
\hline MC & 3 & 45 & & & & 2 & 4 & 9 & 20 & 0 & 18 & 47 \\
\hline MM & 0 & 95 & 24.79 & 18 & 0.13 & 6 & 1 & 14 & 16 & 23 & 16 & 24 \\
\hline MM & 1 & 45 & & & & 11 & 0 & 18 & 16 & 24 & 9 & 22 \\
\hline MM & 2 & 30 & & & & 4 & 6 & 17 & 13 & 10 & 27 & 23 \\
\hline MM & 3 & 109 & & & & 16 & 8 & 17 & 12 & 13 & 15 & 20 \\
\hline ML & 0 & 59 & 52.97 & 12 & $<0.001$ & 2 & 5 & 8 & 17 & 5 & 14 & 49 \\
\hline ML & 1 & 20 & & & & 16 & 6 & 16 & 31 & 6 & 0 & 26 \\
\hline ML & 2 & 201 & & & & 13 & 4 & 18 & 11 & 23 & 17 & 14 \\
\hline Total & & 279 & & & & 10 & 4 & 16 & 14 & 18 & 15 & 22 \\
\hline
\end{tabular}

such counter-intuitive aspects are not considered as artifacts but as the result of ecological mechanisms. For example, field margins planted with trees have not necessarily a 'forest-edge' vegetation type but can have a 'weed' type vegetation due to recurrent use of non-selective herbicide leading to stripping of the soil surface. Conversely, field margins bordering crop fields may reveal a 'forest edge' vegetation type due to the ancient presence of trees which no longer exist. In that sense, Ecobordure can be used to make users question the consequences of their management practices. Keeping the same above examples, the first case may encourage a farmer to stop non-selective herbicide treatments and prefer mechanical ones to limit the establishment of the 'weed" vegetation type (Moonen and Marshall, 2001). The second case may address conservation stakes: how long can we maintain this 'forestedge' vegetation type without a novel tree canopy? Although Ecobordure allows inference on potential drivers of vegetation patterns, Ecobordure has not been validated yet in its ability to measure the change or recover of a vegetation pattern after management practice changes. Performing long term studies would allow us to test the suitability of Ecobordure for monitoring and analyzing changes that occurred in vegetation patterns after changes in structural and management practices, e.g. tree plantation or reduction in herbicide treatment (e.g. Alignier and Baudry, 2015; Alignier, 2018).

On the other hand, by integrating three groups of species which cover a wide range of traits and ecological attributes, Ecobordure may be used to hypothesize on the 'consequences' of observed vegetation patterns, i.e. the potential ecological functions implied in ecosystem services. For example, the delay in flowering between 'forest-edge (earlier in spring and late in summer) and "grassland" (extended flowering period in spring) field margins may offer significant supplementary resources for pollinators in agricultural landscapes (Crawley, 1997). Because of the vegetation architecture, and notably the extensive lateral spread above and below ground of Graminae (Marshall and Moonen, 2002), 'grassland' field margins would offer a dense cover that may reduce the competitiveness and installation of ruderal weeds. In addition, 'grassland' field margins would better contribute to buffer surface fluxes of water and sediment compared with weedy field margins whose vegetation, dominated by annual and ruderal species, has a limited lateral spread and a superficial and fleeting root system (Grime, 1977). However the ability of Ecobordure in predicting such ecological functions still need to be validated. The coupling of Ecobordure with models or indicators evaluating ecosystem services such as the Ricou's indicator for pollination (Ricou et al., 2014) would make the link with ecosystem service more reliable.
Since the design of Ecobordure, a partnership has developed over time between researchers and agricultural teachers and advisers who have shown interest for such indicator. Although we did not perform a "end-use validation" sensu Bockstaller and Girardin (2003), we got some markers of interest and appropriation of Ecobordure by end users. From 2007 to 2017, 10 training sessions on Ecobordure principles and use were organized gathering a total of 173 learners. Two working seminars (in 2012 and 2017, respectively) on the use and applications of Ecobordure gathered 48 and 57 persons, respectively. Several professional domains were represented including agricultural teachers and advisers but also engineers from territorial communities, from environmental or hunting associations. We also worked with agricultural advisers from the center of France to adapt Ecobordure to their region of openfields on calcareous soils, through an adaptation of the list of reference species.

Finally, our experience in Ecobordure design, output and end-user validation enables us to specify its validity domain. In its original form, Ecobordure has been validated for field margins in bocage regions with temperate oceanic climate, on acidic to neutral soil, and dominated by mixed farming, in north-western France. However, Ecobordure can be adapted to a broad spectrum of agricultural regions with caution. Ecobordure may be applied to field margins (perennial linear seminatural elements) delineating fields (excluding free range areas) and pertaining to temperate agricultural regions with agroecological issues on field margin vegetation and more specifically on the three species groups (namely ' forest-edge', 'grassland' and 'weed' species). According to such principles, the use of Ecobordure might not be appropriate in alpine pastures or open wet marshes, with specific wetland species.

\section{Conclusion}

Designed and built for non-specialists, Ecobordure aims to provide agricultural teachers and advisers with information regarding the vegetation patterns of field margins and their drivers. Ecobordure was built upon empirical data and all stages of its construction have been validated (design and output validation sensu Bockstaller and Girardin, 2003). Ecobordure, with appropriate adaptations, can be extended to field margins of a broad spectrum of temperate agricultural and pedoclimatic regions. Referring to Feld et al. (2009), the method developed here is an example of how an indicator with a low degree of complexity allows inference on the drivers associated with observed vegetation patterns of field margins. 


\section{Author contributions}

DLC provided the original idea. DLC, CT and FF designed the indicator. FF, EL and BR collected the data. EL, BR and AA conducted data analyses. AA and CT wrote the manuscript. EL, BR and FF revised the manuscript.

\section{Acknowledgements}

The Ecobordure design was funded by the European Agricultural Guidance and Guarantee Fund (EAGGF). The Ecobordure output validation study was funded by several projects led by our partners: the Biodivea Project aiming at better integrate agriculture and biodiversity in the teaching and experimental farming of agricultural schools (Ministry in charge of Agriculture), the Agrifaune Network Project, aiming at support agricultural practices favorable to the small sedentary fauna and biodiversity, and the European Regional Development Fund for Brittany/France (ERDF-Brittany). The fieldwork for the design of Ecobordure was conducted in the Zone Atelier Armorique, a Long Term Ecological Research (LTER). The authors thank Michel Novak and Jean-Luc Roger for their valuable field assistance. The authors are also grateful to Hugues Boussard who developed the Ecobordure software which allows to mobilize the data, to produce different graphical representations of the Ecobordure triangle, and to export files of different numeric results. Finally, the authors warmly thanks the farmers for their kind participation.

\section{Appendix A. Supplementary data}

Supplementary data associated with this article can be found, in the online version, at http://dx.doi.org/10.1016/j.ecolind.2017.11.046.

\section{References}

Alard, D., Bance, J.-F, Frileux, P.-N., 1994. Grassland vegetation as an indicator of the main agro-ecological factors in a rural landscape: consequences for biodiversity and wildlife conservation in central normandy (France). J. Environ. Manage. 42, 91-109.

Alignier, A., Baudry, J., 2015. Changes in management practices over time explain most variation in vegetation of field margins in Brittany France. Agric. Ecosyst. Environ. 211, 164-172.

Alignier, A., 2018. Changes in a field margin vegetation metacommunity over a 21-year interval and the impacts of structural condition and management. Agric. Ecosyst. Environ. 251, 1-10.

Bockstaller, C., Girardin, P., 2003. How to validate environmental indicators. Agric. Syst. 76, 639-653.

Bockstaller, C., Lasserre-Joulin, F., Slezack-Deschaumes, S., Piutti, S., Villerd, J., Amiaud, B., Plantureux, S., 2011. Assessing biodiversity in arable farmland by means of indicators: an overview. OCL 18, 137-144.

Burel, F., Baudry, J., 1999. Écologie du paysage. Concepts, méthodes et applications. Tec\&Doc, Paris.

Clergué, B., Amiaud, B., Pervanchon, F., Lasserre-Joulin, F., Plantureux, S., 2005. Biodiversity: function and assessment in agricultural areas: a review. Agron. Sustainable Dev. 25, 1-15.

Crawley, M.J., 1997. Plant Ecology. Blackwell Science, Oxford.

de Blois, S., Domon, G., Bouchard, A., 2002. Factors affecting plant species distribution in hedgerows of southern Quebec. Biol. Conserv. 105, 355-367.

Delbaere, B., 2003. An Inventory of Biodiversity Indicators in Europe, 2002. European Environment Agency (EEA), Copenhagen.

Duru, M., Theau, J.P., Cruz, P., 2012. Functional diversity of species-rich managed grasslands in response to fertility, defoliation and temperature. Basic Appl. Ecol. 13, 20-31.

Fahrig, L., Baudry, J., Brotons, L., Burel, F.G., Crist, T.O., Fuller, R.J., Sirami, C., Siriwardena, G.M., Martin, J.-L., 2011. Functional landscape heterogeneity and animal biodiversity in agricultural landscapes. Ecol. Lett. 14, 101-112.

Feld, C.K., da Silva, P.M., Sousa, J.P., de Bello, F., Bugter, R., Grandin, U., Hering, D., Lavorel, S., Mountford, O., Pardo, I., Partel, M., Rombke, J., Sandin, L., Jones, K.B., Harrison, P., 2009. Indicators of biodiversity and ecosystem services: a synthesis across ecosystems and spatial scales. Oikos 118, 1862-1871.

Fisher, B., Turner, R.K., Morling, P., 2009. Defining and classifying ecosystem services for decision making. Ecol. Econ. 68, 643-653.

Forman, R.T., Baudry, J., 1984. Hedgerows and hedgerow networks in landscape ecology. Environ. Manage. 8, 495-510.

Garnier, E., Lavorel, S., Ansquer, P., Castro, H., Cruz, P., et al., 2007. Assessing the effects of land-use change on plant traits, communities and ecosystem functioning in grasslands: a standardized methodology and lessons from an application to 11 European sites. Ann. Bot. 99, 967-985.

Girardin, P., Bockstaller, C., Van der Werf, H., 2000. Assessment of potential impacts of agricultural practices on the environment: the AGRO*ECO method. Environ. Impact Assess. Rev. 20, 227-239.

Grime, J.P., Hodgson, J.G., Hunt, R., 1988. Comparative Plant Ecology: A Functional Approach to Common British Species. Unwin Hyman, London.

Grime, J.P., 1977. Evidence for the existence of three primary strategies in plants and its relevance to ecological and evolutionary theory. Am. Naturalist 111, 1169-1194.

Höft, A., Müller, J., Gerowitt, B., 2010. Vegetation indicators for grazing activities on grassland to be implemented in outcome-oriented agri-environmental payment schemes in North-East Germany. Ecol. Indic. 10, 719-726.

Hill, M.O., Mountford, J.O., Roy, D.B., Bunce, R.G.H., 1999. Ellenberg's indicator values for British plants. ECOFACT Technical Annex Vol. 2 Institute of Terrestrial Ecology, Huntingdon 46pp.

Hill, M.O., 1979. TWINSPAN: A FORTRAN Program for Arranging Multivariate Data in an Ordered Two-Way Table by Classification of the Individuals and Attributes, Section of Ecology and Systematics. Cornell University.

Kleijn, D., Verbeek, M., 2000. Factors affecting the species composition of arable field boundary vegetation. J. Appl. Ecol. 37, 256-266.

Le Coeur, D., Baudry, J., Burel, F., Thenail, C., 2002. Why and how we should study field boundary biodiversity in an agrarian landscape context. Agric. Ecosyst. Environ. 89, 23-40.

Le Coeur, D., Baudry, J., Burel, F., 1997. Field margins plant assemblages: variation partitioning between local and landscape factors. Landscape Urban Plann. 37, 57-71.

Lewis, R.J., Pakeman, R.J., Angus, S., Marrs, R.H., 2014. Using compositional and functional indicators for biodiversity conservation monitoring of semi-natural grasslands in Scotland. Biol. Conserv. 175, 82-93.

Marshall, E.J.P., Moonen, A.C., 2002. Field margins in northern Europe: their functions and interactions with agriculture. Agric. Ecosyst. Environ. 89, 5-21.

Matthews, J.W., Spyreas, G., Endress, A.G., 2009. Trajectories of vegetation-based indicators used to assess wetland restoration progress. Ecol. Appl. 19, 2093-2107.

Meek, B., Loxton, D., Sparks, T., Pywell, R., Pickett, H., Nowakowski, M., 2002. The effect of arable field margin composition on invertebrate biodiversity. Biol. Conserv. 106, 259-271.

Moonen, A.C., Marshall, E.J.P., 2001. The influence of sown margin strips, management and boundary structure on herbaceous field margin vegetation in two neighbouring farms in southern England. Agric. Ecosyst. Environ. 86, 187-202.

Oksanen, J., Guillaume Blanchet, F., Kindt, R., Legendre, P., Minchin, P.R., O'Hara, R.B., Simpson, G.L., Solymos, P., Stevens, M.H.H., Wagner, H., 2015. Vegan: Community Ecology Package. R Package Version 2.3-0. http://CRAN.Rproject.org/package= vegan.

Olson, D.M., Wäckers, F.L., 2007. Management of field margins to maximize multiple ecological services. J. Appl. Ecol. 44, 13-21.

Pervanchon, F., Bockstaller, C., Girardin, P., 2002. Assessment of energy use in arable farming systems by means of an agro-ecological indicator: the energy indicator. Agric. Syst. $72,149-172$

Plantureux, S., Ney, A., Amiaud, B., 2010. Evaluation of the agronomical and environmental relevance of the CAP measure 'flowering grassland'. Grassland in a Changing World: Proceedings of the 23rd General Meeting of the European Grassland Federation 666-668.

Pywell, R.F., Meek, W.R., Hulmes, L., Hulmes, S., James, K.L., Nowakowski, M., Carvell, C., 2011. Management to enhance pollen and nectar resources for bumblebees and butterflies within intensively farmed landscapes. J. Insect Conserv. 15, 853-864.

R Development Core Team, 2014. R: A Language and Environment for Statistical Computing. Vienna, Austria.

Ricou, C., Schneller, C., Amiaud, B., Plantureux, S., Bockstaller, C., 2014. A vegetationbased indicator to assess the pollination value of field margin flora. Ecol. Indic. 45, 320-331.

Schippers, P., Joenje, W., 2002. Modelling the effect of fertiliser, mowing, disturbance and width on the biodiversity of plant communities of field boundaries. Agric. Ecosyst. Environ. 93, 351-365.

Ter Braak, C.F., 1987. The analysis of vegetation-environment relationships by canonical correspondence analysis. In: Prentice, I.C., van der Maarel, E. (Eds.), Theory and Models in Vegetation Science. Springer, Netherlands, pp. 69-77.

Tutin, T., Burges, N., Chater, A., Edmondson, J., Heywood, V., Moore, D., Valentine, D., Walters, S., Webb, D., 1993. Flora Europaea. Cambridge University Press, Cambridge.

van der Werf, H.M.G., Petit, J., 2002. Evaluation of the environmental impact of agriculture at the farm level: a comparison and analysis of 12 indicator-based methods. Agric. Ecosyst. Environ. 93, 131-145.

Wittig, B., Kemmermann, A.R.G., Zacharias, D., 2006. An indicator species approach for result-orientated subsidies of ecological services in grasslands - a study in Northwestern Germany. Biol. Conserv. 133, 186-197. 